\title{
Tracer-flux analysis of sodium and potassium permeability in differentiating mouse spermatozoa
}

\author{
Angele V. McGrady and Denise Meschke \\ Medical College of Ohio, C. S. 10008, Toledo, Ohio 43699, U.S.A.
}

\begin{abstract}
Summary. Heterogeneous populations of developing mouse spermatozoa were isolated from the seminiferous tubules and suspended in media of varied ionic composition. Tracer-flux analysis showed that $\mathrm{P}_{\mathrm{Na}} / \mathrm{P}_{\mathrm{K}}$ in developing spermatozoa is 0.7 which is relatively high and that permeability of the cells to potassium and sodium is dependent on the ionic concentration of the medium.
\end{abstract}

\section{Introduction}

One of the current major questions in reproductive biology concerns the cellular events that lead to differentiation of the spermatozoon to the mature motile condition. During differentiation, striking variations occur not only in cell shape but also in the ionic composition of the developing spermatozoa and their surrounding media, specifically in the ratio of sodium to potassium (Cragle, Salisbury \& Muntz, 1958).

The membrane potential $\left(\mathrm{E}_{\mathrm{m}}\right)$ of cells isolated from mouse testis is dependent on both sodium and potassium concentration gradients (McGrady, 1979). Cuthbert \& Wong (1975) postulated a relatively high permeability ratio of sodium to potassium $\left(\mathrm{P}_{\mathrm{Na}} / \mathrm{P}_{\mathrm{K}}\right)$ based on their study of membrane potential in rat seminiferous tubules. Wong (1976) studied uptake of ${ }^{22} \mathrm{Na}$ into rat seminiferous tubules and found that entry of sodium occurs rapidly and by simple diffusion. Chueng, Hwang \& Wong $(1976,1978)$ showed a significant contribution of sodium as well as potassium to membrane potential of rat epididymal epithelial cells. Zimmerman et al. (1979) studied the uptake of $\mathrm{Na}^{+}$and $\mathrm{K}^{+}$in boar epididymal spermatozoa and suggested that caput cells are more permeable to sodium than are those from the cauda or in the ejaculate. In ejaculated bull spermatozoa the $E_{m}$ was dependent on the intracellular-extracellular potassium ratio (McGrady \& Nelson, 1972, 1973). In ejaculated boar spermatozoa the uptake of ${ }^{42} \mathrm{~K}$ was relatively rapid, whereas movement of ${ }^{22} \mathrm{Na}$ was slow (Crabo, Zimmerman, Moore \& Thornbourgh, 1976). Permeability changes concurrent with development may exist in spermatozoa; specifically, the ratio $\mathrm{P}_{\mathrm{Na}} / \mathrm{P}_{\mathrm{K}}$ appears to decrease as cells progress from the testis to the epididymis and finally to the ejaculate.

The present paper explores fluxes of potassium $\left({ }^{42} \mathrm{~K}\right)$ and sodium $\left({ }^{22} \mathrm{Na}\right)$ in a heterogeneous population of cells isolated from mouse testes.

\section{Materials and Methods}

Preparation of cell samples

Male mice weighing approximately $30 \mathrm{~g}$ were killed by intraperitoneal injection of pentobarbitone sodium. The testes were excised and their capsules removed. The tubules were 
teased into a control medium with the following composition (mmol/l): fructose, $40 ; \mathrm{KCl}, 50$; $\mathrm{NaHCO}_{3}, 35: \mathrm{Na}_{2} \mathrm{HPO}_{4} \cdot \mathrm{H}_{2} \mathrm{O}, 1 \cdot 8 ; \mathrm{MgSO}_{4}, 1 ; \mathrm{NaCl}, 69 \cdot 2$. This is a synthetic medium similar in composition to free flow medium (defined as that obtained by micropuncture of seminiferous tubules (Tuck, Setchell, Waites \& Young, 1970)). Free flow medium was chosen as the control solution because it is considered to be nearly the natural environment of the spermatogenic cells. In the ion substitution experiments, sodium or Tris (Tris-(hydroxylmethyl)-aminomethane) was substituted for potassium (sodium and chloride held constant) and Tris was substituted for sodium (potassium and chloride held constant). No effect of Tris on $E_{m}$ or cell viability was apparent. In another series of experiments, ouabain ( $1 \mu \mathrm{M}-1 \mathrm{mM})$ was added to the control medium. Ouabain is an inhibitor of $\mathrm{Na}^{+}-\mathrm{K}^{+}$-activated $\mathrm{Mg}^{2+}$-dependent ATPase, an enzyme which is active in cation transport in mature and developing spermatozoa (Voglmayr, White \& Quinn, 1969; O'Donnell \& Ellory, 1970). Osmolarity was maintained at approximately 320 mosmol/1, and $\mathrm{pH} 7.3$ in all the solutions. All experiments were carried out at room temperature $\left(24^{\circ} \mathrm{C}\right)$ as were previous measurements of $\mathrm{E}_{\mathrm{m}}$ and of intracellular sodium and potassium.

The teased seminiferous tubules were minced and agitated for $20 \mathrm{~min}$ in control medium, with $0.3 \%$ trypsin (ICN Pharmaceuticals, Inc. Life Science Division, Cleveland, Ohio, U.S.A.) and $0.002 \%$ DNase (Worthington Biochemicals, Freehold, New Jersey, U.S.A.) according to Romrell, Bellvé \& Fawcett (1976). The preparation was filtered through Nitex Cloth, $102 \mu \mathrm{m}$ mesh (Tetko, Inc., Elmsford, New York, U.S.A.) into $12 \mathrm{ml}$ conical centrifuge tubes. This procedure retains cell aggregates and pieces of seminiferous tubules while allowing isolated germinal cells to pass through (Steinberger, 1975). The cells were washed twice in free flow medium to remove trypsin and centrifuged at $1200 \mathrm{~g}$ for $10 \mathrm{~min}$ in a Sorval Type NSE centrifuge. Cells treated with trypsin did not differ in membrane potential from cells not subjected to trypsin. Dye exclusion (eosin-nigrosin) was used to assess viability of the cells as previously described (McGrady \& Nelson, 1972). Viability of the cells was 70-80\%.

\section{Tracer-flux measurements}

The supernatant was decanted and the pellet resuspended in $3 \mathrm{ml}$ of control or experimental medium. For efflux experiments, cells were preloaded for $1 \mathrm{~h}$ in labelled control medium containing $10 \mu \mathrm{Ci}{ }^{42} \mathrm{~K} / \mathrm{ml}$ or $5 \mu \mathrm{Ci}{ }^{22} \mathrm{Na} / \mathrm{ml}$ (New England Nuclear, Boston, Massachusetts, U.S.A.). Specific activity was maintained constant at changing $\mathrm{K}^{+}$and $\mathrm{Na}^{+}$levels. The cells were centrifuged at $1200 \mathrm{~g}$ for $10 \mathrm{~min}$ and washed once in non-radioactive medium (containing 109 $\mathrm{mM}-\mathrm{Na}^{+}$and $50 \mathrm{mM}-\mathrm{K}^{+}$). The cells were resuspended in the control medium or in one of the experimental media, and 25 or $50 \mu$ aliquots of cells were taken with calibrated micropipettes at predetermined time intervals. Protein was precipitated by the addition of $0.5 \mathrm{ml} 20 \%$ trichloroacetic acid. The samples were homogenized and centrifuged for $20 \mathrm{~min}$ at $2000 \mathrm{~g}$, and the supernatant was decanted and added to a scintillation cocktail. The amounts of ${ }^{42} \mathrm{~K}$ and ${ }^{22} \mathrm{Na}$ were measured with a Beckman Biogamma Counter, and background counts were subtracted. Corrections were made for $29 \%$ extracellular space as determined previously using $\left[{ }^{3} \mathrm{H}\right]$ inulin (McGrady, 1979). This value is close to that (21\%) used by Wong (1976).

For the uptake experiments, the cells were incubated for various times in labelled control or experimental media containing $10 \mu \mathrm{Ci}^{42} \mathrm{~K} / \mathrm{ml}$ or $5 \mu \mathrm{Ci}^{22} \mathrm{Na} / \mathrm{ml}$. Aliquots of cells were removed, washed with non-radioactive control medium and treated as described above for efflux experiments.

Influx of potassium was also studied by cellular uptake of ${ }^{42} \mathrm{~K}$ in the presence of various concentrations of ouabain. Influx of sodium was determined by uptake of ${ }^{22} \mathrm{Na}$. Although the flux measurements were made on a heterogeneous population of spermatogenic cells, previous electrophysiological analysis showed no difference in $E_{m}$ (which in turn depends on the concentration of potassium and sodium) between the spermatogenic cells. 


\section{Calculations}

The assumptions underlying these calculations derive from Hodgkin \& Katz (1949), Solomon (1960), Tupper (1972) and Tupper \& Powers (1973).

The data from ${ }^{42} \mathrm{~K}$ efflux was plotted as:

$$
-\ln \frac{R_{i}(t)}{R_{i}\left(t_{0}\right)}
$$

where $R_{i}(t)$ is the c.p.m. inside the cells at various times and $R_{i}\left(t_{0}\right)$ is c.p.m. inside the cell at time zero. From the slope of this line the rate constant, $k_{0}$, can be found. The unidirectional efflux $\mathrm{J}_{0}(\mathrm{~K})$ in $\mathrm{mol} / \mathrm{cm}^{2} / \mathrm{sec}$ was determined from:

$$
\mathrm{J}_{0}=k_{0}\left[\mathrm{C}_{\mathrm{i}} \mathrm{V}_{\mathrm{i}}\right]
$$

where $k_{0}$ is the rate constant, $\mathrm{V}_{\mathrm{i}}$ is the cell volume and $\mathrm{C}_{\mathrm{i}}$ is the total intracellular potassium concentration. Therefore $\left[\mathrm{C}_{\mathrm{i}} \mathrm{V}_{\mathrm{i}}\right]$ is the total $\mathrm{K}^{+}$content. Intracellular and extracellular $\mathrm{Na}^{+}$and $\mathrm{K}^{+}$concentrations were previously determined by flame photometry as described by McGrady (1979). Although the specific activity of the external medium was normally kept low, it is well known that when these cells are suspended in low potassium medium, they lose intracellular potassium. Therefore, there is some error inherent in this calculation since it assumes no backflux. To determine the cell volume per sample, cell dimensions were measured with an ocular micrometer. Also, the developmental stage of each cell was determined on the basis of cell size and shape, density of nucleus and presence and length of the flagellum (Leblond \& Clermont, 1952; Romrell et al., 1976). The approximate percentage of cell types was as follows: spermatogonia, $6 \%$; spermatocytes, $22 \%$; spermatids, $45 \%$; testicular spermatozoa, $17 \%$; Sertoli and Leydig cells, <4\%; other cells, $6 \%$. These values are comparable to those described by Meistrich, Bruce \& Clermont (1973) for trypsin-prepared suspensions from mouse testes. To find the total volume, the volume per cell type was multiplied by the number of that cell type per sample. The total cell volume of a $50 \mu$ sample was $2.73 \times 10^{-2} \mathrm{~cm}^{3}$.

Results for ${ }^{22} \mathrm{Na}$ uptake can be plotted as:

$$
-\ln \left[1-\frac{R_{i}(t)}{R_{i}(\infty)}\right] \text { versus time }
$$

where $R_{i}(t)$ is the intracellular c.p.m. at various times and $R_{i}(\infty)$ is the intracellular c.p.m. at apparent isotope equilibrium. From the slope of this line the rate constant $k_{\mathrm{i}}$ is found. The influx $\left(\mathrm{mol} / \mathrm{cm}^{2} / \mathrm{sec}\right)$ is determined by:

$$
\mathrm{J}_{\mathrm{i}}=k_{\mathrm{i}}\left[\mathrm{C}_{\mathrm{i}} \mathrm{V}_{\mathrm{i}}\right]
$$

The problem of backflux also arises here, in that, as intracellular ${ }^{22} \mathrm{Na}$ increases with time, some ${ }^{22} \mathrm{Na}$ will leak or will be pumped back out of the cells. This simple interpretation of the data is justified in order to give a first approximation of the permeability constants in these cells. Furthermore, the permeability coefficients $P_{K}$ and $P_{N a}(\mathrm{~cm} / \mathrm{sec})$ can be calculated from the formulae of Hodgkin \& Katz (1949):

$$
\begin{aligned}
& \mathrm{P}_{\mathrm{K}}=\frac{\mathrm{J}_{0}(\mathrm{~K})}{(\mathrm{K})_{\mathrm{i}}} \cdot \frac{1-\mathrm{e}^{-\mathrm{V} F / \mathrm{R} T}}{\mathrm{~V} F / \mathbf{R} T} \\
& \mathrm{P}_{\mathrm{Na}}=\frac{\mathrm{J}_{\mathrm{i}}(\mathrm{Na})}{(\mathrm{Na})_{0}} \frac{1-\mathrm{e}^{-\mathrm{V} F / \mathrm{R} T}}{\mathrm{~V} F / \mathbf{R} T}
\end{aligned}
$$

where $F$ is the Faraday, $96500 \mathrm{C} / \mathrm{mol} ; \mathbf{R}$ is the gas constant, $8.3 \mathrm{~J} /$ degree mol; and $T$ is the absolute temperature in degrees Kelvin, i.e. $297 \mathrm{~K}$. Values for $\mathrm{V}, \mathrm{K}_{\mathrm{i}}, \mathrm{Na}_{\mathrm{i}}, \mathrm{K}_{\mathbf{0}}$ and $\mathrm{Na}_{0}$ were 
determined by electrophysiological and flame photometric techniques as reported previously (McGrady, 1979). Since passive diffusion is driven by the electrochemical gradient and both the chemical and electrical components will vary with varying $\mathrm{K}_{0}$ and $\mathrm{Na}_{0}$, the values previously determined were used in all the calculations as appropriate.

\section{Results}

Flux of ${ }^{42} K$

The uptake of ${ }^{42} \mathrm{~K}$ in control and ouabain-modified media is shown in Text-fig. 1. Uptake of ${ }^{42} \mathrm{~K}$ in cells suspended in free flow medium (which contains $109 \mathrm{mM}-\mathrm{Na}^{+}$and $50 \mathrm{mM}-\mathrm{K}$ ) was biphasic, increasing rapidly during the first $15 \mathrm{~min}$, then continuing to increase slowly until equilibrium was reached at $2 \mathrm{~h}$. When ouabain was added to the control medium, $\mathrm{K}_{\mathrm{i}}$ decreased due to an inhibition of active transport. At apparent equilibrium there was $33 \%$ less isotope in cells treated with $10^{-6} \mathrm{M}$-ouabain and $54 \%$ less at $10^{-3} \mathrm{M}$.

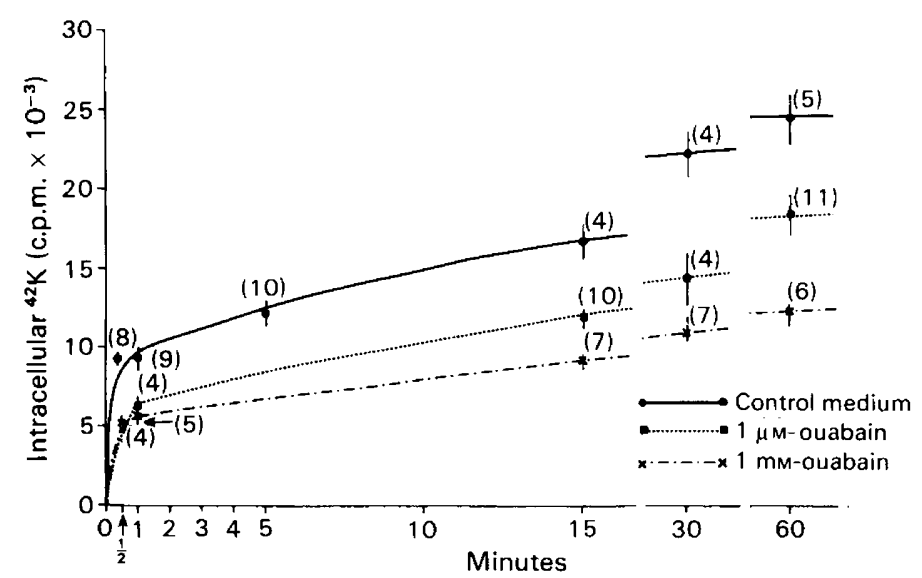

Text-fig. 1. Uptake of ${ }^{42} \mathrm{~K}$ by mouse testicular spermatogenic cells in control and ouabainmodified media. Values are mean \pm s.e.m. for the no. of replicates indicated in parentheses.

Movement of potassium was analysed by monitoring efflux of ${ }^{42} \mathrm{~K}$ from preloaded cells. The cells were re-suspended in non-radioactive media with varied potassium concentrations. Efflux was accelerated by suspension of cells in low potassium medium $\left(1 \mathrm{~mm}-\mathrm{K}^{+}\right)$, while an increase in

Table 1. Calculation of the permeability constants for mouse testicular cells suspended in control medium containing $50 \mathrm{~mm}-\mathrm{K}^{+}, 109 \mathrm{~mm}-\mathrm{Na}^{+}$and free of $\mathrm{Ca}^{2+}$

\begin{tabular}{|c|c|c|}
\hline $\begin{array}{l}\text { Previous values (McGrady, } \\
\mathrm{E}_{\mathrm{m}}=-4.6 \pm 0.3 \mathrm{mV} \\
\text { Intracellular sodium: } \\
\text { Intracellular potassium: }\end{array}$ & $\begin{array}{l}\text { 1979) } \\
74 \mathrm{mM} \\
70 \mathrm{~mm}\end{array}$ & $\begin{array}{l}\text { Extracellular sodium: } 109 \mathrm{~mm} \\
\text { Extracellular potassium: } 50 \mathrm{mM}\end{array}$ \\
\hline $\begin{array}{l}\text { Present stud } \\
\mathbf{J}_{\mathrm{o}}(\mathrm{K}) \\
\mathrm{J}_{\mathrm{i}}(\mathrm{Na}) \\
\mathbf{P}_{\mathbf{K}} \\
\mathbf{P}_{\mathrm{Na}} \\
\mathbf{P}_{\mathrm{Na}} / \mathbf{P}_{\mathbf{K}}\end{array}$ & $\begin{array}{l}\text { dy } \\
3.75 \times \\
4.18 \times \\
5.45 \times \\
4.2 \times \\
0.72\end{array}$ & $\begin{array}{l}10^{-7} \mathrm{~mol} / \mathrm{cm}^{2} / \mathrm{sec} \\
10^{-7} \mathrm{~mol} / \mathrm{cm}^{2} / \mathrm{sec} \\
10^{-6} \mathrm{~cm} / \mathrm{sec} \\
10^{-6} \mathrm{~cm} / \mathrm{sec}\end{array}$ \\
\hline
\end{tabular}


extracellular potassium over that in control medium $\left(50 \mathrm{mM}-\mathrm{K}^{+}\right)$correspondingly decreased ${ }^{42} \mathrm{~K}$ efflux (Text-fig. 2). The rate constant of the efflux $\left(k_{0}\right)$ was derived from the slope of Equation 1 versus time (Text-fig. 2, insert). $P_{K}$ was calculated from Equations 2 and 5 (Table 1). $P_{K}$ was inversely related to the concentration of potassium in the medium (Table 2).
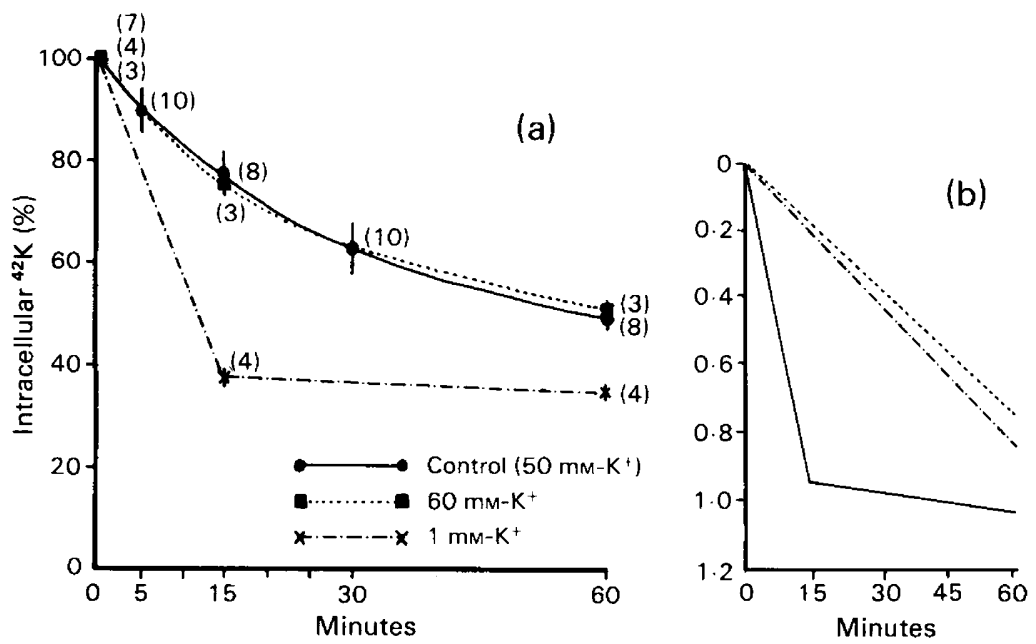

Text-fig. 2. (a) Efflux of ${ }^{42} \mathrm{~K}$ from preloaded mouse testicular spermatogenic cells into media of different ionic composition. Cells were preloaded for $1 \mathrm{~h}$ in ${ }^{42} \mathrm{~K}$ control medium, washed once in non-radioactive medium and re-suspended in an experimental medium. In $1 \mathrm{~mm}-\mathrm{K}^{+}$medium, Tris was substituted for potassium; in $60 \mathrm{~mm}-\mathrm{K}^{+}$medium, potassium was substituted for sodium. Values are means \pm s.e.m. for the no. of replicates in parentheses. (b) Plot of

$$
-\ln \frac{R_{\mathbf{i}}(t)}{R_{i}\left(t_{0}\right)}
$$

versus time from which the rate constant is determined.

Table 2. The effect of ion concentration on permeability of cells isolated from mouse testes

\begin{tabular}{lcc}
\hline Medium & $\mathrm{P}_{\mathrm{Na}}(\mathrm{cm} / \mathrm{sec})$ & $\mathrm{P}_{\mathrm{K}}(\mathrm{cm} / \mathrm{sec})$ \\
\hline Control $\left(\mathrm{Ca}^{2+}{ }^{-f r e e}\right), 50 \mathrm{mM}-\mathrm{K}^{+}$, & $4.2 \times 10^{-6}$ & $5.45 \times 10^{-6}$ \\
$\quad 109 \mathrm{mM}-\mathrm{Na}^{+}$ & - & $3.61 \times 10^{-5}$ \\
$1 \mathrm{mM}-\mathrm{K}^{+}\left(\right.$Tris replaced), $109 \mathrm{mM}-\mathrm{Na}^{+}$ & - & $5.89 \times 10^{-6}$ \\
$60 \mathrm{mM}-\mathrm{K}^{+}, 99 \mathrm{mM}-\mathrm{Na}^{+}$ & - & - \\
$50 \mathrm{mM}-\mathrm{K}^{+}, 50 \mathrm{mM}-\mathrm{Na}^{+}$(Tris replaced) & $3.3 \times 10^{-6}$ & - \\
Control $+5 \mathrm{mM}-\mathrm{Ca}^{2+}$ & $2.2 \times 10^{-6}$ & - \\
\hline
\end{tabular}

Flux of ${ }^{22} \mathrm{Na}$

The presence of $5 \mathrm{~mm}-\mathrm{Ca}^{2+}$ decreased uptake of ${ }^{22} \mathrm{Na}$ by approximately $30 \%$. Decreasing extracellular sodium ( $50 \mathrm{~mm}-\mathrm{Na}$ ) produced a decline in ${ }^{22} \mathrm{Na}$ uptake of $20 \%$ at equilibrium. The rate constant $\left(k_{\mathrm{i}}\right)$ of the influx of sodium was determined from the slope of the plot of Equation 3 (Text-fig. 3, insert). $\mathrm{P}_{\mathrm{Na}}$ was calculated from Equations 4 and 6 , and was $4.2 \times 10^{-6} \mathrm{~cm} / \mathrm{sec}$ in control medium (Table 1). Decreased sodium and addition of calcium lowered ${ }^{22} \mathrm{Na}$ influx (Table 2). Efflux of ${ }^{22} \mathrm{Na}$ from preloaded cells was measured in control medium and in sodium-free medium (Text-fig. 4). Considering time zero as $100 \%, 10 \%$ of the intracellular labelled sodium 

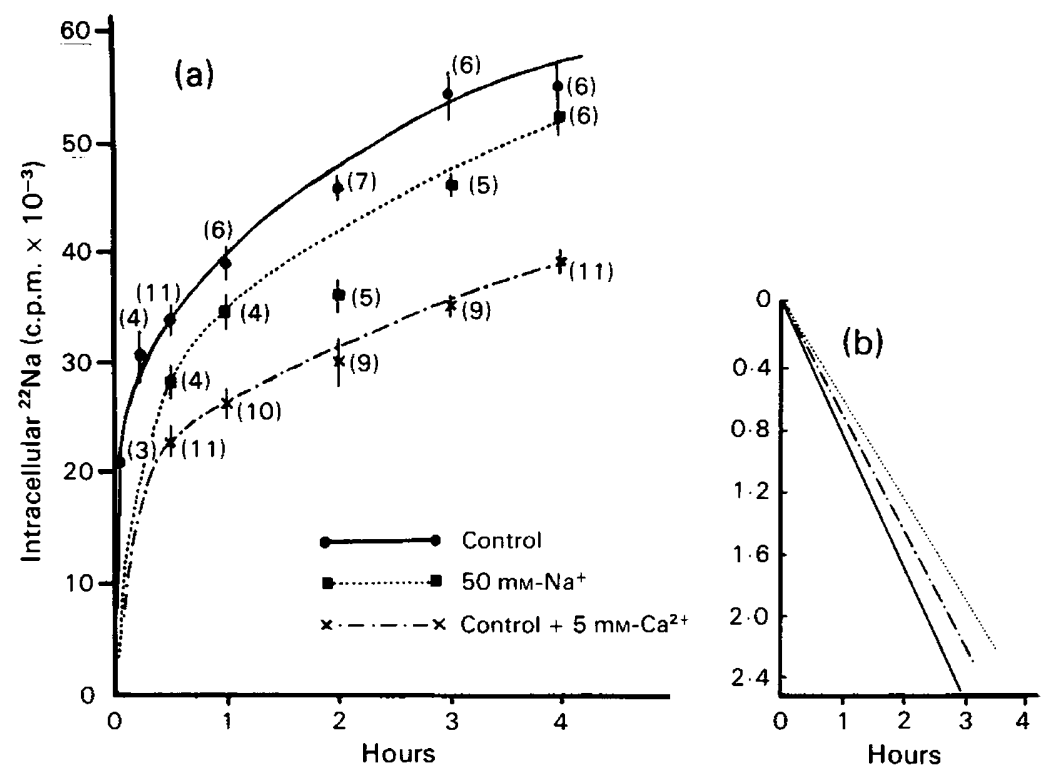

Text-fig. 3. (a) Uptake of ${ }^{22} \mathrm{Na}$ in media of different ionic composition. Values are means \pm s.e.m. for the no. of replicates indicated in parentheses. (b) Plot of

$$
-\ln \left[\frac{1-\mathbf{R}_{\mathbf{i}}(\mathrm{t})}{\mathbf{R}_{\mathbf{i}}(\infty)}\right]
$$

versus time from which the rate constant is determined.

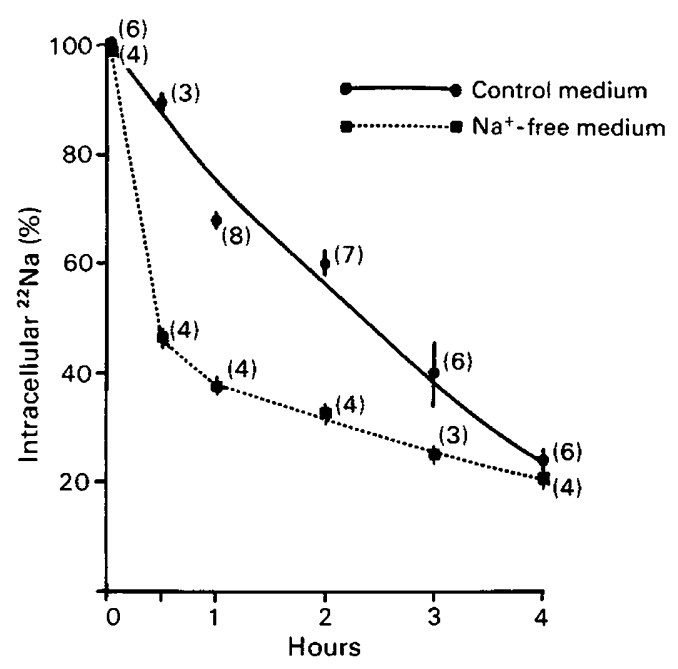

Text-fig. 4. Efflux of ${ }^{22} \mathrm{Na}$ from preloaded cells into control (109 $\left.\mathrm{mm}-\mathrm{Na}^{+}\right)$and sodium-free medium (Tris replaced sodium; potassium and chloride remained constant). Cells were preloaded for $1 \mathrm{~h}$ in ${ }^{22} \mathrm{Na}$ control medium, washed once in non-radioactive medium, and resuspended in the experimental medium. Values are mean \pm s.e.m. for the no. of replicates indicated in parentheses.

had run out in $1 \mathrm{~h}$ from cells suspended in control medium and $55 \%$ had run out from cells suspended in sodium-free medium. Approximately $40 \%$ of the labelled sodium remained in the cells after $4 \mathrm{~h}$ of incubation in both suspending media. 


\section{Discussion}

It is generally believed that transmembrane potentials in non-excitable cells are similar to those in nerve and muscle, i.e. diffusion potentials are maintained by active transport (Peterson, 1976). In non-excitable cells, however, the $E_{m}$ is usually less negative, cell membrane resistance is less and relative permeability to sodium is higher than in excitable cells (Williams, 1970). Accordingly, in mature (bull), epididymal (rat) and developing (mouse) spermatozoa, membrane potential and cell membrane resistance were relatively low compared to values for excitable cells (McGrady \& Nelson, 1972, 1973; Cuthbert \& Wong, 1975; Cheung et al., 1976, 1978; McGrady, 1979). In mature spermatozoa, potassium was the major contributor to $E_{m}$, with secondary influences due to sodium and chloride. The cell membrane was permeable to all three ions whose intracellular concentration could be manipulated by changing the external concentration (McGrady \& Nelson, 1972, 1973).

In mouse spermatocytes and spermatids, $E_{m}$ was dependent on both potassium and sodium with $\mathrm{E}_{\mathrm{m}}$ linearly related to the extracellular concentration of both ions. Since chloride did not affect $E_{m}$, the Goldman equation in the form

$$
\mathrm{E}_{\mathrm{m}}=\frac{\mathbf{R} T}{F} \ln \left(\frac{(\mathrm{K})_{0}+\mathrm{P}_{\mathrm{Na}} / \mathrm{P}_{\mathrm{K}}(\mathrm{Na})_{0}}{(\mathrm{~K})_{\mathrm{i}}+\mathrm{P}_{\mathrm{Na}} / \mathrm{P}_{\mathrm{K}}(\mathrm{Na})_{\mathrm{i}}}\right)
$$

was used to determine the relative contribution of sodium and potassium to $E_{m}$. The best fit of $E_{m}$ versus $K_{0}$ was obtained with a $P_{N a} / P_{K}$ value between 0.5 and 0.6 . In addition, $P_{N a} / P_{K}$ varied with extracellular ion concentration (McGrady, 1979).

The present paper investigated the permeability of the membrane of isolated cells from the mouse testis by direct calculation of $\mathbf{P}_{\mathrm{Na}} / \mathbf{P}_{\mathrm{K}}$ via tracer flux analysis. $\mathbf{P}_{\mathrm{Na}} / \mathbf{P}_{\mathrm{K}}$ in control medium (109 mM-Na ${ }^{+}, 50 \mathrm{mM}-\mathrm{K}^{+}$) was 0.7 , suggesting a relatively high sodium permeability (Table 1). This value was close to the predicted $\mathrm{P}_{\mathrm{Na}} / \mathrm{P}_{\mathrm{K}}$ of $0.5-0.6$ from electrophysiological measurements alone and calculated with the Goldman equation. In low potassium medium $\left(1 \mathrm{~mm}-\mathrm{K}^{+}\right.$, sodium constant), $P_{K}$ increased to $3.61 \times 10^{-5} \mathrm{~cm} / \mathrm{sec}$ (Table 2). Efflux of potassium under these conditions occurred very rapidly, confirming the previous findings of hyperpolarization and a decline in intracellular potassium (McGrady, 1979). With increased $K_{0}, P_{K}$ declined. Previous electrophysiological analysis of the effects of ouabain (Cuthbert \& Wong, 1975; McGrady, 1979) showed a decrease of $20-35 \%$ in membrane potential which occurred within $15 \mathrm{~min}$. The present results tend to substantiate the earlier analysis in that a ouabain-induced decrease in $\mathrm{K}_{\mathrm{i}}$ concentration occurred at $10^{-6}$ and $10^{-3}$ M-ouabain.

Wong (1976) and Reisin \& Cereijido (1969) studied ${ }^{22} \mathrm{Na}$ uptake by rat seminiferous tubules but did not calculate the permeability constant. The present work corroborates their findings that decreasing external sodium decreased ${ }^{22} \mathrm{Na}$ uptake; the uptake curve over the first $20 \mathrm{~min}$ is similar. The presence of calcium as well as the extracellular sodium concentration affected $\mathrm{P}_{\mathrm{Na}}$ (Table 2).

Data from other cell systems indicate a relationship between membrane permeability and development. In echinoderm embryos (Tupper \& Powers, 1973) and in embryonic heart cells (DeHaan, 1970), the permeability to sodium declines with maturation. Developing sperm cells, whether spermatocytes or spermatids, appear to be responsive electrophysiologically to both sodium and potassium, and membrane permeability is dependent on the ion concentration of the medium. Nevertheless, differentiating spermatozoa maintain homeostasis while challenged with the variations in the $\mathrm{Na}: \mathrm{K}$ ratio that occur in the reproductive tract (Tuck et al., 1970; Wyker \& Howards, 1977). In mature ejaculated spermatozoa (McGrady \& Nelson, 1972, 1973), sensitivity to sodium was less apparent, with potassium clearly being the dominant ion. Zimmerman et al. (1979) found that caput spermatozoa responded more strongly to sodium than did cauda or ejaculated boar spermatozoa. 
Although permeability constants for epididymal or ejaculated spermatozoa have not been calculated for mouse spermatozoa, the hypothesis that membrane permeability $\left(\mathrm{P}_{\mathrm{Na}} / \mathrm{P}_{\mathrm{K}}\right)$ declines with development in spermatogenic cells must be given further consideration.

This work was supported by NIH Grant HD 94246 and Biomedical Research Support Grant 94898 (Medical College of Ohio) to A. McG. We also thank Dr Paul Brand and Dr G. Colin Budd for assistance in revising the manuscript, Dr Leonard Nelson for discussion, and Sharon FitzGerald for editing.

\section{References}

Chueng, Y.M., Hwang, J.C. \& Wong, P.Y.D. (1976) Epithelial membrane potentials of the epididymis in rats. J. Physiol., Lond. 263, 280-286.

Chueng, Y.M., Hwang, J.C. \& Wong, P.Y.D. (1978) Membrane potentials of epithelial cells in the epididymis of rats, ionic and castration effects. Comp. Biochem. Physiol. 59, 403-407.

Crabo, B.G., Zimmerman, K., Moore, R. \& Thornbourgh, R. (1976) Movements of sodium and potassium into ejaculated boar spermatozoa suspended in seminal plasma and a biological salt solution. Biochim. Biophys. Acta 444, 875-885.

Cragle, R.G., Salisbury, G.W. \& Muntz, J. (1958) Distribution of bulk and trace minerals in bull reproductive tract fluids and semen. J. Dairy $S c i .41$, 1273-1277.

Cuthbert, A.W. \& Wong, P.Y.D. (1975) Intracellular potentials in cells of the seminiferous tubules of rats. J. Physiol, Lond. 248, 173-191.

DeHann, R. (1970) The potassium sensitivity of isolated embryonic heart cell increases with development. Devl Biol. 23, 226-240.

Hodgkin, A.L. \& Katz, B. (1949) The effect of sodium ions on the electrical activity of the giant axon of the squid. J. Physiol., Lond. 108, 37-77.

Leblond, C.P. \& Clermont, Y. (1952) Spermiogenesis of rat, mouse, hamster and guinea pig as revealed by periodic acid-fuchsin sulfurous acid technique. $A \mathrm{~m}$. J. Anat. 90, 167-215.

McGrady, A. (1979) Electrophysiology of differentiating mouse spermatozoa. J. cell. Physiol. 99, 223-231.

McGrady, A. \& Nelson, L. (1972) Cationic influences on sperm biopotentials. Expl Cell Res. 73, 192-196.

McGrady, A. \& Nelson, L. (1973) Electrophysiology of bull spermatozoa. Expl Cell Res. 76, 349-352.

Meistrich, M.L., Bruce, W.R. \& Clermont, Y. (1973) Cellular composition of fractions of mouse testis cells following velocity sedimentation separation. Expl Cell Res. 79, 213-227.

O'Donnell, J.M. \& Ellory, J.C. (1970) The binding of cardiac glycosides to bull spermatozoa. Experientia 26, 20-21.

Peterson, O.H. (1976) Electrophysiology of mammalian gland cells. Physiol. Rev. 56, 535-577.
Reisin, I. \& Cereijido, M. (1969) Na fluxes in single, isolated seminal tubules of the rat. Biophys. J. 9, 194.

Romrell, L.J., Bellvé, A.R. \& Fawcett, D.W. (1976) Separation of mouse spermatogenic cells by sedimentation velocity. Devl Biol. 49, 119-131.

Solomon, A.K. (1960) Compartmental Methods of Kinetic Analysis in Mineral Metabolism, Vol. I, Part A, pp. 119-140. Eds C. L. Comar \& J. F. Bronner. Academic Press, New York.

Steinberger, A. (1975) Culture and FSH responses of Sertoli cells isolated from sexually mature rat testis. In Hormonal Regulation of Spermatogenesis, Vol. 2, pp. 399-411. Eds F. S. French, V. Hansson, E. M. Ritzen \& S. N. Nayfeh. Plenum Press, New York.

Tuck, R.R., Setchell, B.P., Waites, G.M.H. \& Young, J.A. (1970) The composition of fluid collected by micropuncture and catheterization from the seminiferous tubules and rete testis of rats. Pflugers Arch. Ges. Physiol. 318, 225-243.

Tupper, J.T. (1972) The ionic basis of membrane potential in the early asterias embryo. Devl Biol. 29, 273-282.

Tupper, J.T. \& Powers, D. (1975) Changes in ion permeability and membrane potential during early echinoderm development: electrophysiological and tracer-flux determinations. J. Zool., Lond. 184, 353364.

Voglmayr, J.K., White, I.G. \& Quinn, P.J. (1969) A comparison of adenosinetriphosphatase activity in testicular and ejaculated sperm of the ram. Biol. Reprod. 1, 121-129.

Williams, J.A. (1970) Origin of transmembrane potentials in nonexcitable cell. $J$. theoret. Biol. $\mathbf{2 8}$, 287-296.

Wong, P.Y.D. (1976) Uptake of sodium into rat isolated seminiferous tubules in vitro. Jap. J. Physiol. 26, 321-331.

Wyker, R. \& Howards, S. (1977) Micropuncture studies of the motility of rete testes and epididymal spermatozoa. Fert. Steril. 28, 108-112.

Zimmerman, K.J., Crabo, B.G., Moore, R., Weisberg, S., Deibel, F.C. \& Graham, E.F. (1979) Movements of sodium and potassium into epididymal boar sperm atozoa. Biol. Reprod. 21, 173-181. 